\title{
GEORGE AND PRITI
}

\section{Binary love.}

\section{ANAND ODHAV NARANBHAI}

$\mathrm{P}$ riti Sinvi, 59: "Oh, George." George Kwame, 67: "Oh, Priti." Priti, a Kenyan-born extremophile biologist doing postdoctoral work at the JS Moons Institute and recent recipient of the 'African Academy of Science Young Scientist Award for Stellar Research': "I love you, George."

George, the smartest engineering graduate on the continent, who discovered a new particle while on a summer elective on V645 Centauri and then, for his $\mathrm{PhD}$, perfected the use of the particle as the next-generation fuel source: "I love you, Priti."

They nestled in a quiet, hidden corner of the spaceship's maintenance floor, a wall of glass separating them from the loneliness of space. Two bodies fused into one, a shadow against the white splendour of a solar flare.

"George, can it be?"

"Yes, Priti. You are my life-force, my reason for breathing. I can't live without you."

"Oh, George, I wish that were enough. But life is much more complicated than that. We have to think about the long term. You and I ... we're so different. Not morally or habitually or like that, but culturally. You know what I'm talking about, George."

"Priti, I've told you not to listen to your parents too much. I suppose we will have differences like all couples do, but we can work through them. Our only difference is the colour of our skin. I love you too much to let outdated opinions based on an ancient pigment get in the way."

"You can say that easily now, George, but it will be very different once we have been together for a while and this dream that we are in senesces. And you know, my parents have been around for 200 years and both are on their third marriages, so they know how relationships work. [Sighs] I keep thinking about my twin aunts who ran away with handsome boys from Mars, only to end up in messy divorces. One of them is now an alcoholic theoretical dramatist and the other one is an artist-in-residence on Pluto!"

"It doesn't matter what happens to other people. I've told you, I don't care about that and I'm not like them. I love you for who you are on the inside and outside."

Priti put her head on George's chest. George held her in his gloved arms.

"Oh, George. I don't know what to do. My heart is telling me one thing, and my brain

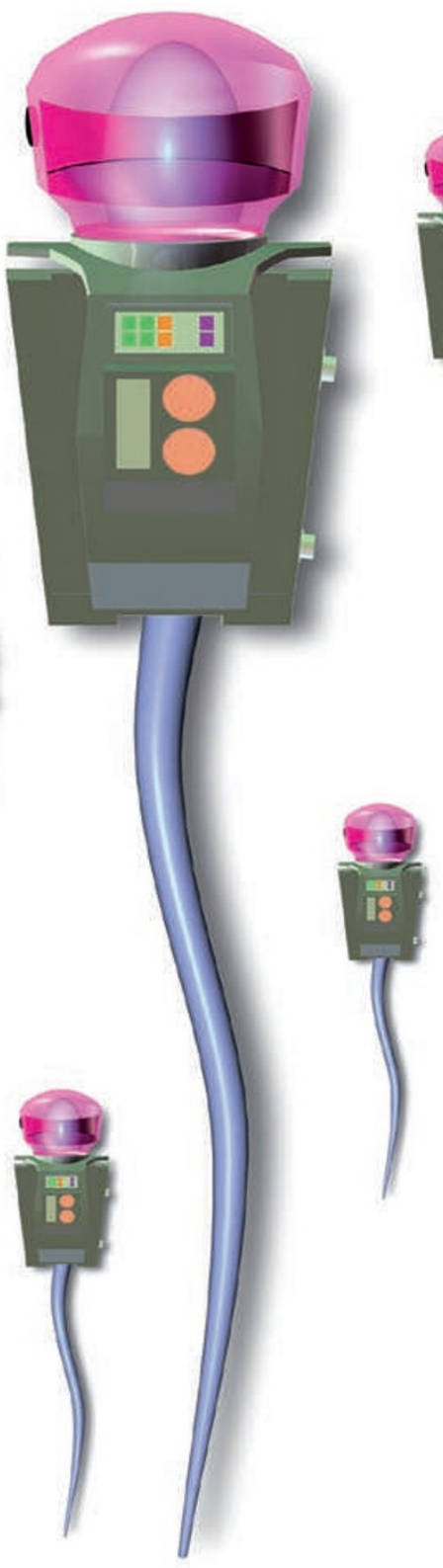

every permutation. At the end, I just couldn't decide which column outweighed the other.

Whenever I choose the second column, my heart just can't accept it. My subconscious neural circuits become restless."

"That means it's love, Priti."

"I know it's love, George. But love is an effervescent and evanescent thing."

"Not mine!"

"Oh, George! Don't try to charm me. We have to be serious. We live at opposite ends of the Solar System. We'll only see each other once, maybe twice every five years."

"I'm not trying to charm you, Priti. I'm being as honest as I can. We'll talk to each other every day and can see each other after work using the virtual conferencing function on that cellphone I gave you for your birthday. Even if we are light years apart, it'll be like we're right next to each other."

"It's not the same. There's so much more that words alone can't possibly express. George, we have to think carefully about this. There'll be other girls that you'll meet, you know. Girls closer than me. Girls that will look prettier, younger, more qualified than me."

"That's not fair. You know I don't even look twice at a girl with a short spacesuit. You're the only one I have eyes for, Priti. Hell, I never even thought about another woman before you. I just kept my head down and worked at my fuel cell. Priti, I may not be a suave, weight-pumping, grand-commandertype guy, but I know I am a good man, I know I am a smart man, I know I'm a man of principle, a man of science. I will take care of you for the next 200 million years. I will never let any water shortage or ship malfunction or stupid cancer take my life partner from me. I will never let anybody interfere with my girl's work out of professional jealousy. I will fly to the ends of the Universe without going to the loo once for you. I will suffer any pain, any punishment, any injury, any disappointment, anything, but not the pain of losing you. I want to make you the happiest women in the Universe ... Priti Sinvi, will you marry me?"

"But what about children?"

"I'll post you my sperm."

"Oh, George, I do!"

Anand Odhav Naranbhai is a third-year medical student at the Nelson R. Mandela School of Medicine at the University of KwaZulu Natal in Durban, South Africa. 